\title{
Lack of ceramide generation in TF-1 human myeloid leukemic cells resistant to ionizing radiation
}

\author{
Alain P. Bruno ${ }^{1}$, Guy Laurent ${ }^{1,2}$, Dietrich Averbeck ${ }^{3}$, \\ Cécile Demur ${ }^{2}$, Jacques Bonnet ${ }^{4}$, Ali Bettaïeb', \\ Thierry Levade ${ }^{5}$ and Jean-Pierre Jaffrézou ${ }^{1,6}$ \\ 1 CJF INSERM 9503, Centre Claudius Régaud, Toulouse Cédex 31052, France \\ 2 Service d'Hématologie, Centre Hospitalier Universitaire Purpan, Toulouse \\ 31059, France \\ ${ }^{3}$ UMR218 CNRS, Institut Curie, Paris Cédex 75005, France \\ 4 Département de Radiothérapie, Centre Claudius Régaud, Toulouse Cédex \\ 31052, France \\ 5 INSERM U.466, Centre Hospitalier Universitaire Rangueil, Toulouse 31403, \\ France \\ ${ }^{6}$ corresponding author: CJF INSERM 9503, Centre Claudius Régaud, 20 rue du \\ pont St Pierre, Toulouse Cédex 31052 France. \\ e.mail: jaffrezou@regaud-tlse.fnclcc.fr
}

Received 30.5.97; revised 25.7.97; accepted 12.9.97

Edited by D. Green

\begin{abstract}
The mechanism(s) by which ionizing radiation (IR) induces cell death is of fundamental importance in understanding cell sensitivity and resistance. Here we evaluated the response to IR of two subclones of the autonomous human erythromyeloblastic cell line TF-1: TF-1-34 (which expresses CD34) and TF-1-33 (which lacks CD34). In clonogenic assays, TF-1-34 cells were found to be relatively less sensitive to IR compared to TF-1-33 cells based on the $D_{0}$ determination (3.01 vs 1.56 Gy). Furthermore, after IR at 12 Gy, TF-1-33 cell viability decreased by $\sim 50 \%$ within $24 \mathrm{~h}$, whereas TF-1-34 cell growth was unaffected during this time. Gradual loss of TF-1-34 cell viability was observed only after $48 \mathrm{~h}$. Morphological and molecular analysis revealed that TF-1-33 cells died of apoptosis, and TF-1-34 cells of delayed reproductive cell death. While IR produced comparable amounts of DNA double strand breaks (DSB) in both cell lines, TF-1-34 retained DSB much longer than TF-1-33 suggesting that radioresistance and the defective apoptotic response of TF-1-34 cells was not related to a higher DNA repair capacity. However, the lack of an apoptotic response in TF-1-34 was correlated to the absence of a sphingomyelin (SM)-ceramide (CER) signaling pathway. Indeed, IR triggered in TF-1-33 cells but not in TF$1-34$, SM hydrolysis (25\% at $12 \mathrm{~Gy}$ ) and CER generation $(>50 \%)$ through the activation of neutral but not acid sphingomyelinase. Synthetic cell permeate CER induced apoptosis in both TF-1-33 and TF-1-34 cells. This study indicates that alterations of the SM-CER signaling pathway can significantly influence the cell death process as well as the survival of acute myeloid leukemia cells after IR exposure.
\end{abstract}

Keywords: Apoptosis; resistance; myeloid leukemia; irradiation; ceramide

Abbreviations: PBS, phosphate buffered saline; DAPI, 4', $6^{\prime}$ diamidino 2-phenylindole; EDTA, ethylene diaminetetraacetic acid; SM, sphingomyelin; CER, ceramide; SMase, sphingomyelinase; TNF, tumor necrosis factor; IR, ionizing radiation; DSB, double-strand breaks; AML, acute myeloid leukemia

\section{Introduction}

In acute myeloid leukemia (AML), IR is commonly used as part of the conditioning regimen, before autologous or allogeneic bone marrow transplantation. While little is known about the response of immature AML cells to IR at both the cellular and molecular levels, it is believed that IR contributes to the eradication of the most immature residual leukemic cell population. However, studies in mice and subhuman primates have demonstrated that normal immature hematopoietic cells are relatively resistant to IR compared to more mature myeloid cells (Ploemacher et al, 1992). Therefore, it is conceivable that immature AML cells also display natural resistance to IR compared to more mature compartments of leukemic myelopoiesis.

DNA double-strand breaks are believed to be the principal (or most important) lesions underlying IR-induced cell death. They are caused by either direct interaction of IR with DNA or indirect action via the production of free radicals following the radiolysis of water (Radford, 1986). Above a certain threshold dose, delineated by the shoulder of the survival curve, irradiated cells fail to correctly repair DNA. The residual DNA breaks lead to chromosome aberrations, rendering cells incapable of sustained cell division (Radford, 1986). However, at lower IR doses, where cell survival is detectable, the onset of cell death generally occurs after one or more cell divisions (Hofer, 1970) which lead to the terms mitotic or delayed reproductive cell death (Chang and Little, 1991).

IR-induced cell death has also been associated with the induction of apoptosis. In fact, the inductibility of apoptosis by IR is generally correlated with radiosensitivity (Meyn et al, 1993; Ling et al, 1994). In contrast to mitotic cell death, apoptosis is a relatively rapid and irreversible process which occurs within a few hours following IR exposure. Although documented in proliferating cell lines as well as tumor cells (Bump et al, 1994), IR-induced apoptosis was originally described in nonmitotic cells such as lymphocytes, which lead to the term of interphase cell death (Yamada and Ohyama, 1988; Soldatenkov et al, 1989).

The recent description of ceramide (CER) as a potential mediator of IR-induced apoptosis has attracted a great deal 
of attention (Haimovitz-Friedman et al, 1994; Santana et al, 1996). This signaling cascade consists in SM hydrolysis through the activation of a sphingomyelinase (SMase) with concomitant generation of CER which can mediate the apoptotic process (Santana et al, 1996; Hannun, 1996). In fact, the SM-CER pathway has been implicated in the apoptotic process of tumor cells treated with an increasing number of cytotoxic agents including TNF $\alpha$ (Obeid et al, 1993), antibodies directed against the Fas/APO-1 protein (Cifone et al, 1994), stress-inducing agents such as UV and $\mathrm{H}_{2} \mathrm{O}_{2}$ (Verheij et al, 1996) as well as antileukemic agents (Jaffrézou et al, 1996; Zhang et al, 1996). However, as far as IR is concerned, it remains unclear whether or not the activation of the SM-CER cycle occurs in human tumor cells. If this were the case, it is conceivable that any alteration of this pathway, upstream and/or downstream of CER generation, may inhibit IR-induced apoptosis, and subsequently favor mitotic cell death; a delayed and less drastic response which would allow for DNA repair and perhaps increase the fraction of surviving tumor cells.

In order to address this important question, we evaluated the cellular response to IR of TF-1-34 cells, an autonomous subclone of the erythro-myeloblastic TF-1 AML cell line that expresses CD34 (an early differentiation antigen), compared to TF-1-33, another TF-1 subclone which lacks CD34 expression. TF-1-34 cells were found to be relatively less sensitive to IR than TF-1-33 cells based on the $90 \%$ lethal dose. We show herein that irradiated TF-1-34 cells exhibited mitotic cell death while TF-1-33 cells displayed an apoptotic interphase cell death. Moreover, the lack of TF-1-34 apoptotic response was correlated to the failure of the induction of the SM-CER pathway. Our study indicates that the alteration of the SMCER signaling pathway can significantly influence the cell death process as well as the survival of AML cells after IR exposure.

\section{Results}

\section{Cell survival after irradiation}

TF-1-34 and TF-1-33 cells were exposed to increasing IR doses and assayed for their capacity to form colonies in methyl cellulose. Clonogenic assays were performed to obtain a quantitative assessment of the ability of irradiated cells to survive (Figure 1A). Radiosensitivity can be expressed in terms of $D_{0}$ for the two cell lines. The $D_{0}$ were 3.01 Gy $\left(\alpha=0.23 \mathrm{~Gy}^{-1}, \beta=3.02 \times 10^{-2} \mathrm{~Gy}^{-1}\right)$ for TF-1-34 and 1.56 Gy $\left(\alpha=0.59 \mathrm{~Gy}^{-1}, \quad \beta=3.11 \times 10^{-2} \mathrm{~Gy}^{-1}\right)$ for TF-1-33 $(P<0.01)$. The $\mathrm{D}_{0}$ determinations suggest that the sub-clone TF-1-34 is more resistant to IR than TF-1-33.

\section{Viability assays}

Unirradiated TF-1-34 and TF-1-33 cells presented a doubling time of approximately $24 \mathrm{~h}$ when seeded at a cellular concentration of $4 \times 10^{5} / \mathrm{ml}$. Under these conditions TF-1 cells grew exponentially until day 4 after which cells became confluent and rapidly died between day 5 and day 6 (Figure 1B). In preliminary experiments, cells were exposed to varying doses of $\operatorname{IR}(2,6,12$, and 20 Gy) and cell viability was measured by trypan blue exclusion. The dose of $12 \mathrm{~Gy}$ was determined as the minimal dose required to achieve total loss of cell viability within 5 days in both TF-1-34 and TF-1-33. However, TF-1-34 and TF-133 cells exposed to 12 Gy exhibited dramatically different responses. Indeed, irradiated TF-1-34 cell growth was unaffected during the first $24 \mathrm{~h}$, then was reduced until day 3 after which a gradual loss of cell viability was observed; no viable cell was detectable at day 5 . In contrast, in TF-1-33 loss of cell viability was observed as soon as $24 \mathrm{~h}(\sim 50 \%)$ and dropped as a linear function of the time with no viable cell detectable at day 3 . These findings suggested that after 12 Gy IR exposure TF-1-34 cells proceeded through a complete cell cycle followed by cell death whereas TF-1-33 death occurred within one doubling time.

\section{Characterization of IR-induced cell death}

Twenty-four-hours after exposure to 12 Gy IR, DAPI staining of TF-1-33 cells revealed morphological changes characteristic of apoptosis with reduction of cell volume, chromatin fragmentation and apoptotic bodies whereas TF-1-34 remained essentially unchanged. At $48 \mathrm{~h}$, while the majority of TF-1-33 cells were apoptotic, TF-1-34 morphological changes consisted in cell volume increase, plurinucleated giant cells but no apoptotic features (Figure 1C). At $72 \mathrm{~h}$, while no viable TF-1-33 cells were detected, the TF-1-34 cell population consisted of both necrotic and plurinucleated giant cells.

Spectrofluorometric measurement of DNA fragmentation showed that IR induced a dose and time dependent DNA fragmentation in TF-1-33 cells. This was detectable as soon as $6 \mathrm{~h}$ with a maximum of $34 \%$ DNA fragmentation at $48 \mathrm{~h}$ for $12 \mathrm{~Gy}$ IR (Figure 2A). No significant DNA fragmentation was detected in TF-1-34 cells whatever the time of analysis (up to 5 days) and the IR dose (up to $20 \mathrm{~Gy}$ ). Similar results were found after a 6 Gy irradiation (data not shown).

DNA gel electrophoresis confirmed IR-induced oligonucleosomal DNA fragmentation in TF-1-33 but not in TF-1-34 cells. Indeed, in TF-1-33 conventional agarose gel electrophoresis revealed DNA laddering which was faintly visible at $6 \mathrm{~h}$ but clearly detectable at $48 \mathrm{~h}$ for 12 Gy IR (Figure 2B). In contrast, no DNA laddering was observed in TF-1-34 cells up to $96 \mathrm{~h}$. Since it has been reported that internucleosomal DNA fragmentation, which follows DNA macrofragmentation of chromatin loops, can be absent in certain forms of apoptosis (Oberhammer et al, 1993), we also investigated DNA macrofragmentation using pulsedfield gel electrophoresis. These experiments revealed DNA fragments comprised between $600 \mathrm{Kbp}$ and $50 \mathrm{Kbp}$ which preceded DNA ladder formation in TF-1-33 but not in TF-134 cells (Figure 2C). Finally, analysis of phosphatidylserine externalization by flow cytometry, using annexin $\mathrm{V}$ fluorescein isothiocyanate, showed significant annexinpositive TF- $1-33$ cells ( $>20 \%$ ) as soon as $3 \mathrm{~h}$ post-12 Gy IR, whereas TF-1-34 cells remained negative throughout the experiment (data not shown). 


\section{Cell cycle analysis}

PI-BrdU double staining showed major cell cycle changes in the two TF-1 subclones after IF exposure; however, significant differences between TF-1-33 and TF-1-34 were found (Figure 3 ). Irradiated TF-1-33 cells (12 Gy) displayed a decrease in $\mathrm{G} 1$ content, an accumulation in $\mathrm{S}$ phase cells and a moderate G2-M block as soon as $12 \mathrm{~h}$, followed by a progressive increase of subG1 cell content $(A D N<2 n$ which was consistent with the detection of apoptotic cells and DNA fragmentation. Altogether these results suggested that IRtriggered apoptosis mainly occurred in S phase accumulated cells. This was confirmed by PI-dUTP-FITC double staining (data not shown). In TF-1-34 cells exposed to the same dose, we observed no modification of the cell cycle during the first $24 \mathrm{~h}$ (a result which is consistent with the doubling of the population during this time period) thereafter the most significant cell cycle change consisted in a G2-M block and
A

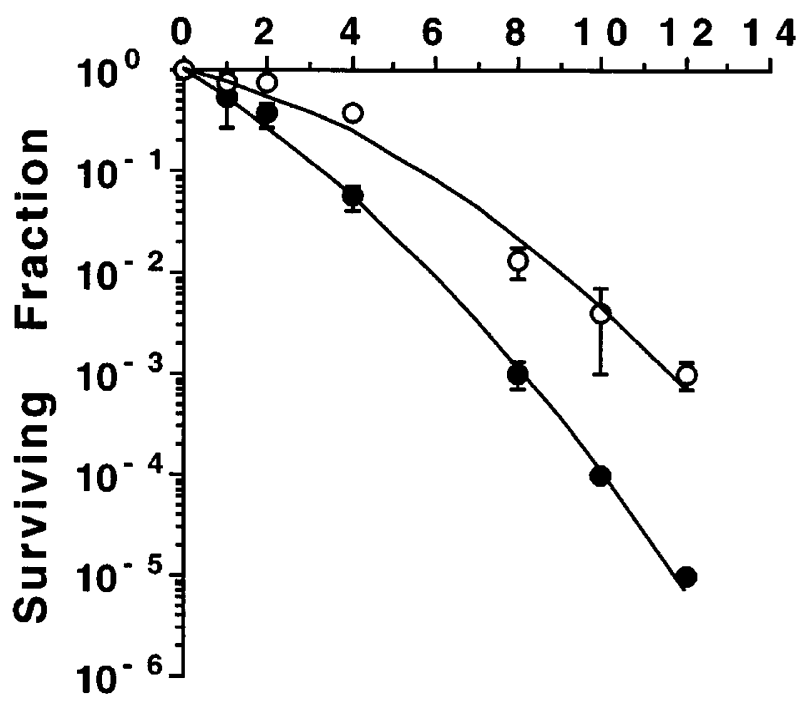

C
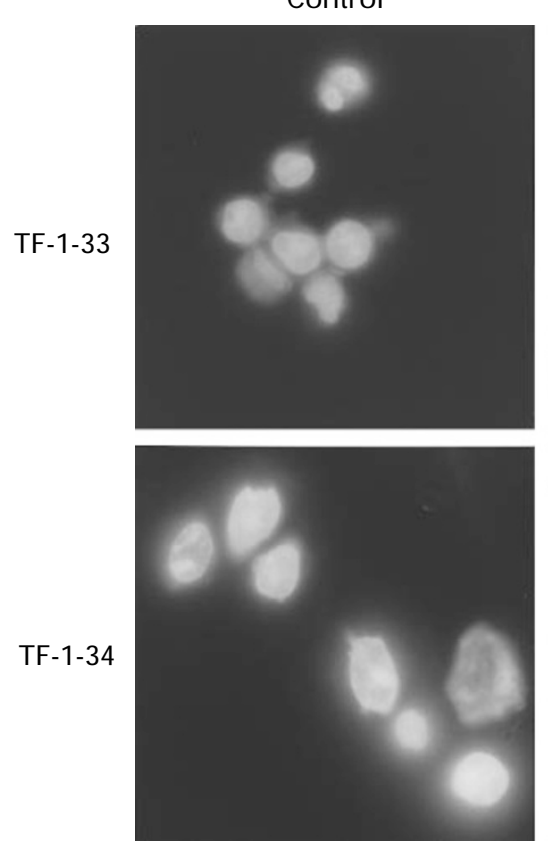

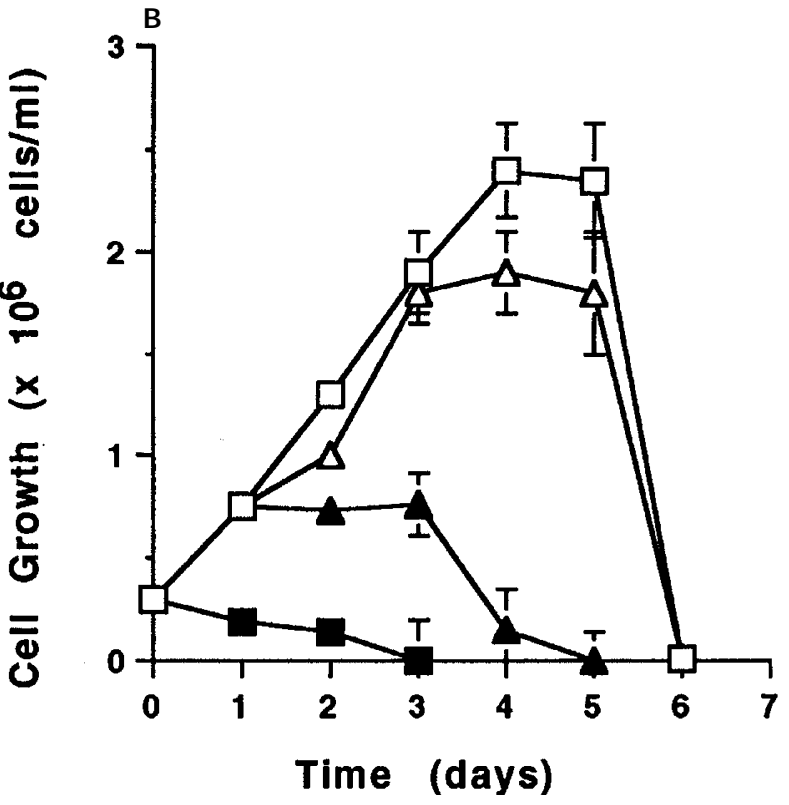

12 Gy IR
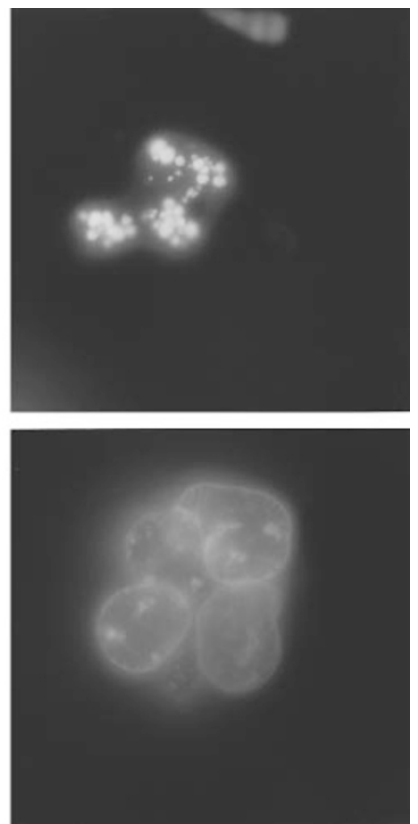

Figure 1 Characterization of IR induced cell death. (A) Clonogenic survival of TF-1-33 $(\mathbf{O})$ and TF-1-34 $(O)$ cells treated with graded doses of IR. Irradiated cells were cultured in methylcellulose for 7 days at $37^{\circ} \mathrm{C}$. Colonies containing more than 20 cells were enumerated. Points are the mean of triplicate determination \pm S.E.M. (B) Viability curves for TF-1-33 ( $\mathbf{\square}, \square)$ and TF-1-34 $(\mathbf{\Lambda}, \triangle)$ cells treated with (closed) or without (open symbol) IR at the dose of 12 Gy. After IR, cells were counted each $24 \mathrm{~h}$, using trypan blue. Points are the mean of triplicate determination \pm S.E.M. (C) Morphological analysis of IR induced cell death. TF-1-33 and TF-1-34 cells were treated with or without $12 \mathrm{~Gy} \mathrm{IR}$, respectively. After $48 \mathrm{~h}$, cells were stained with $0.1 \mu \mathrm{g} / \mathrm{ml} \mathrm{DAPI}$ for $30 \mathrm{~min}$ and viewed at a magnification of $100 \times$ 


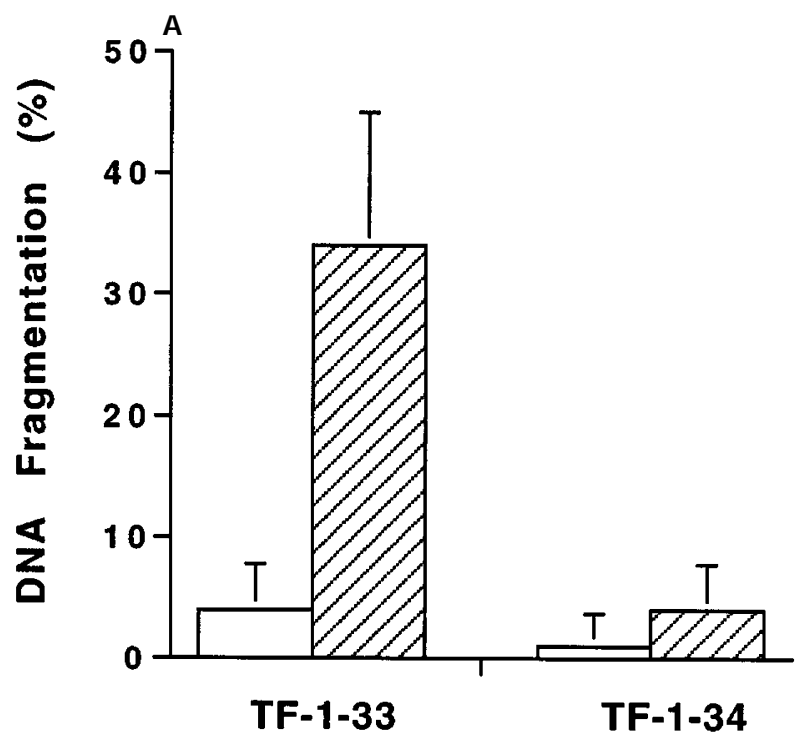

B
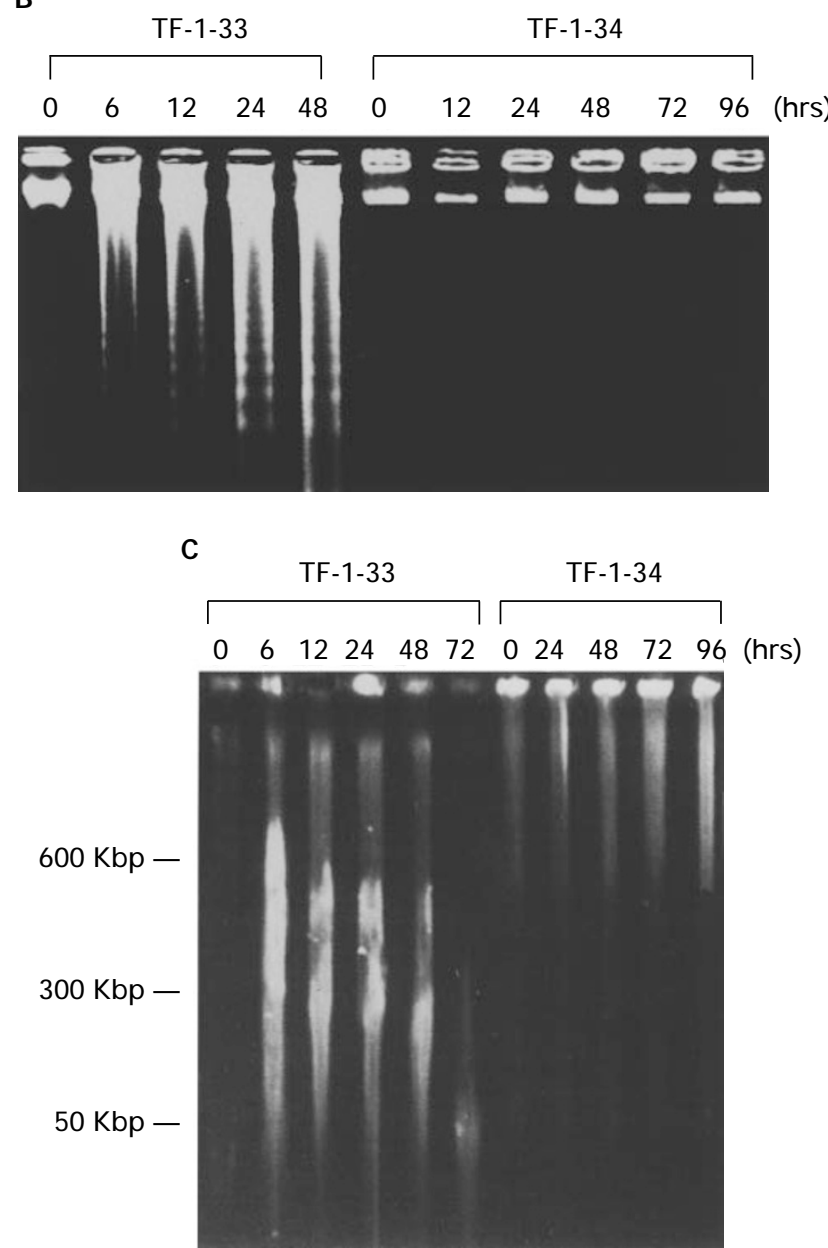

Figure 2 Detection of DNA fragmentation in TF-1-33 and TF-1-34 cells after $\gamma$-IR at the dose of 12 Gy. (A) Control cells $(\square)$ or irradiated cells $(\square \backslash \lambda)$ were harvested after $48 \mathrm{~h}$ incubation and quantitative DNA fragmentation was determined by the spectrofluorimetric DAPI procedure (see Materials and Methods). Data are the mean \pm S.E.M. of three independent determinations. (B) Apoptosis-associated DNA oligonucleosomal fragmentation in TF-1-33 and TF-1-34 cells treated by IR. The formation of oligonucleosomal fragments the appearance of hyperploid cells with DNA content $>4 n$ detectable at $48 \mathrm{~h}$ which progressively increased in parallel with the loss of cell viability. Altogether these results suggested that irradiated TF-1-34 cells proceeded through a normal cell cycle, reentered into G1, achieved complete DNA replication before they were transiently blocked at the G2-M transition and died from abortive mitosis.

\section{DNA repair}

DSB are believed to be responsible for IR-induced lethality. To investigate the possible relation between DSB and TF-1 cells response to IR, the induction of DSB was measured by pulsed-field agarose gel electrophoresis in each cell line. The induction of DSB from 1 to $10 \mathrm{Mbp}$ increased linearly with the dose, and was similar, if not identical, in TF-1-33 and TF-1-34 cells (Figure 4). The DNA repair capacities of the two cell lines were also measured $3 \mathrm{~h}$ after $12 \mathrm{~Gy}$, as DSB rejoining is generally virtually complete in IR sensitive cells within $2-3 \mathrm{~h}$ at $37^{\circ} \mathrm{C}$ (Dhermain et al, 1995; Foray et al, 1996). In these experiments we found that TF-1-33 cells exhibited much higher DNA repair capacity than TF-1-34 cells. Indeed, DSB were totally removed within $3 \mathrm{~h}$ in TF-1-33 cells whereas the percentage of residual DSB in TF-1-34 was as high as $50 \%$.

\section{SM hydrolysis and CER generation}

To ascertain whether IR could activate the SM cycle in TF-1 cells, cells were prelabeled with ${ }^{3} \mathrm{H}$-choline to equilibrium for $48 \mathrm{~h}$. As shown in Figure 5, 12 Gy exposure triggered a SM cycle (hydrolysis and resynthesis) in TF-1-33 but not in TF-134. In TF-1-33 cells about 25\% SM hydrolysis was detected 2 min after irradiation and SM content returned to baseline level at 8 min post-irradiation. SM hydrolysis was detected for doses as low as 2 Gy and its magnitude reached about $30 \%$ for 20 Gy (Figure $5 A$ ). In order to identify the product of SM hydrolysis triggered by IR in TF-1-33 cells, intracellular CER was quantitated by the diacylglycerol kinase method. Basal CER levels was similar for both TF-1-33 and TF-1-34 cells with $308.25 \mathrm{pmol} / \mathrm{mg}, \pm 80.29$. As shown in Figure 9, we found a significant burst in intracellular CER concentrations (over $50 \%$ at 12 Gy) which was observed concurrently with SM hydrolysis, i.e. at 2-4 min after irradiation. However, no CER production was detected in TF-1-34 cells (Figure 5B). Furthermore, treatment with $25 \mu \mathrm{M}$ exogenous C6-CER induced $25 \pm 3 \%$ and $28 \pm 4 \%$ DNA fragmentation at $24 \mathrm{~h}$ in the two TF-1 subclones, indicating that the apoptotic signaling pathway downstream of CER was intact in TF-1-34 cells.

\section{SMase stimulation}

Since the product of IR-induced SM hydrolysis is CER, the enzyme involved in this reaction is a SMase. Both neutral

was determined at various time points by lysing cells, and submitting the DNA to $1.8 \%$ agarose gel electrophoresis. Results are representative of five independent experiments. (C) DNA macrofragmentation in TF-1-33 and TF-134 cells after IR. DNA of treated or untreated cells was extracted at various time points (see Materials and Methods), and submitted to $1 \%$ agarose electrophoresis pulsed-field electrophoresis. Results are representative of four independent experiments 
TF-1-33
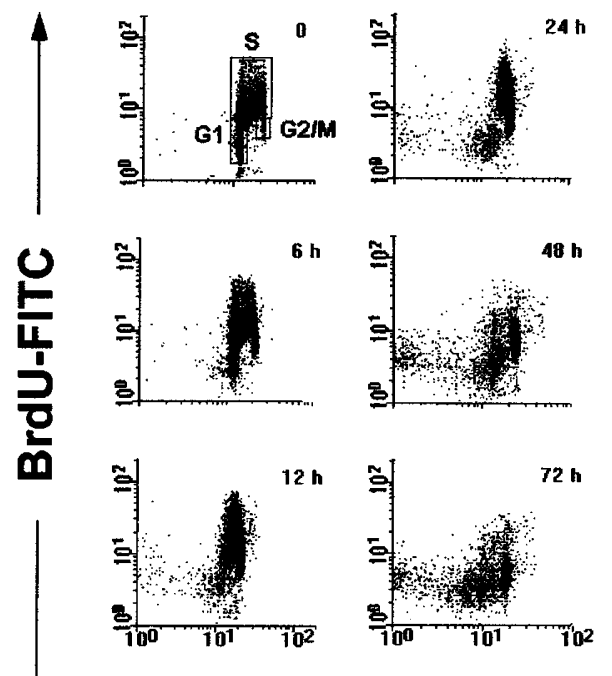

\section{TF-1-34}
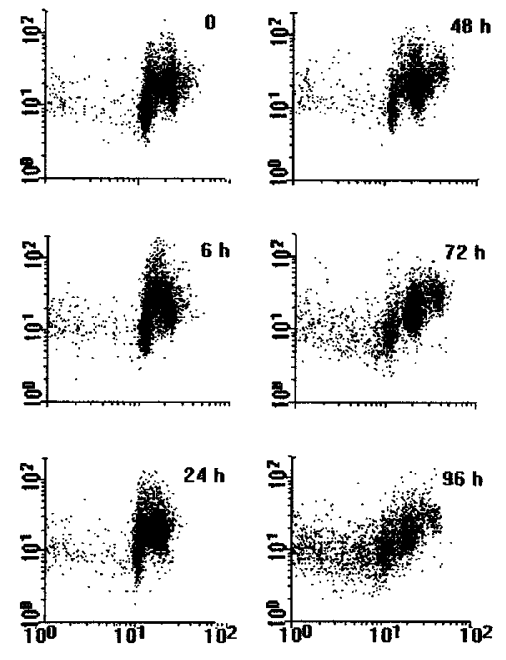

PI

Figure 3 Cell-cycle changes in TF-1-33 and TF-1-34 cells after a 12 Gy IR exposure. Irradiated or unirradiated cells were stained at the indicated time with the $\mathrm{BrdU}$, harvested, fixed and double stained with an FITC-conjugated anti-BrdU antibody and propidium iodide. Cell-cycle analysis was performed on a fluorescenceactivated cell sorter. BrdU-FITC fluorescence is on the Y-axis, and DNA content, measured by propidium iodide fluorescence, is on the $\mathrm{X}$-axis

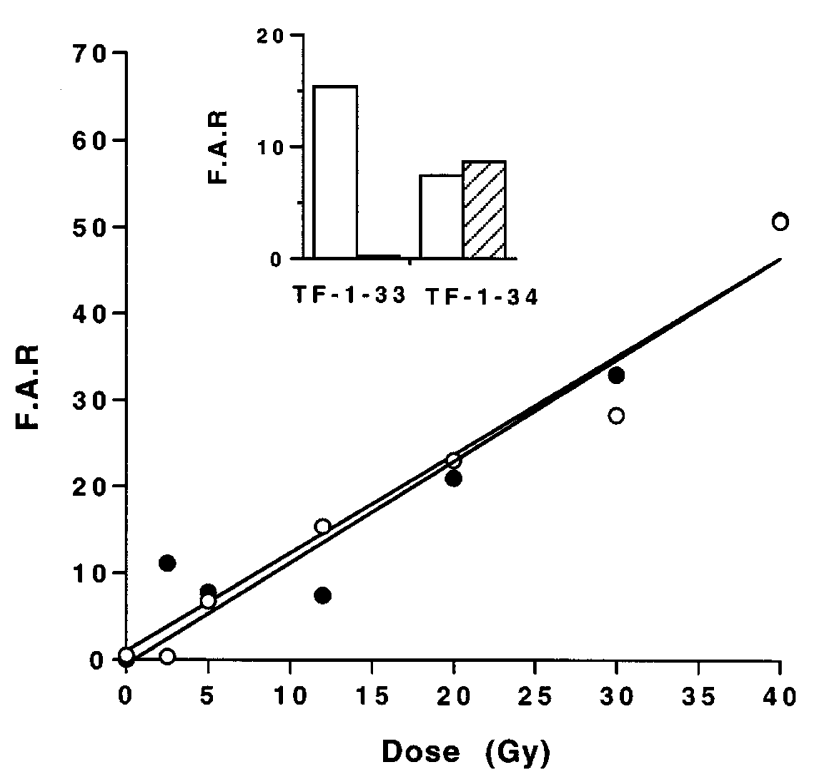

Figure 4 Presence of DSB measured in TF-1-33 and TF-1-34 cells after IR. Quantification of methyl- ${ }^{14} \mathrm{C}$-thymidine-labeled DNA fragments released from the wells after pulsed-field gel electrophoresis was performed for TF-1-33 $(O)$ and TF-1-34 (-) Percentage of the fraction of activity released (FAR) as a function of IR dose. Insert: Repair of DSB measured in TF-1-33 and TF-1-34 cells after IR. Radio-labeled DNA fragments released from the wells after pulsed-field gel electrophoresis were fixed and FAR analysis were performed directly $(\square)$ after IR at $12 \mathrm{~Gy}$ or after $3 \mathrm{~h}$ at $37^{\circ} \mathrm{C}(\mathrm{E} / \triangle)$

(Haimovitz-Friedman et al, 1994) and acidic (Santana et al, 1996) SMases have been reported to be activated in IRtriggered SM hydrolysis, depending on the cell type. To determine the identity of the SMase(s) implicated in the SM cycle in TF-1-33 cells, measured at 2 min (SM hydrolysis peak) both acidic SMase and neutral, magnesium-dependent SMase activities as previously described (Wiegmann et al, 1994; Jaffrézou et al, 1996). As shown in Figure 6, IR exposure (12 Gy) resulted in a $25 \%$ stimulation of neutral SMase activity in TF-1-33 cells but not in TF-1-34, whereas acid SMase activity remained unchanged.

\section{Discussion}

The present study shows that 12 Gy of IR induces interphase apoptotic cell death in the erythro-myeloblastic TF-1-33 but not in TF-1-34 cells. IR-induced cell death has been associated with the induction of apoptosis which is generally correlated with radiosensitivity (Meyn et al, 1993; Ling et al, 1994). However, as our study shows, a defective apoptotic response to IR may not have significant consequences in terms of IR-induced cytotoxicity above a certain threshold dose. Indeed, at high doses (12-20 Gy), IR was very efficient in eliminating 'resistant' TF-1-34 cells as evidenced by both viability and clonogenic assays. Within this dose-range, we observed that after one round of cell division, TF-1-34 cells died following a prolonged arrest in G2-M. Morphological studies identified plurinucleated cells with hyperploid DNA cellular content, suggesting that some cells proceeded to abnormal mitosis before dying. Such a delayed reproductive cell death (Radford, 1986), also termed mitotic death (Chang and Little, 1991), which was first described in IR treated cells, has also been observed in cells treated with low doses of some anticancer compounds such as bleomycin (Tounetki et al, 1993). These findings suggested that TF-1-34 cell death 
resulted from a failure to induce a G2-M block-DNA repair mechanism during the first post-IR cell cycle, which subsequently lead to mitotic cell death (mitotic catastrophe). The reason for which the G2 checkpoint did not occur is unclear. Indeed, G2 arrest is commonly observed within the
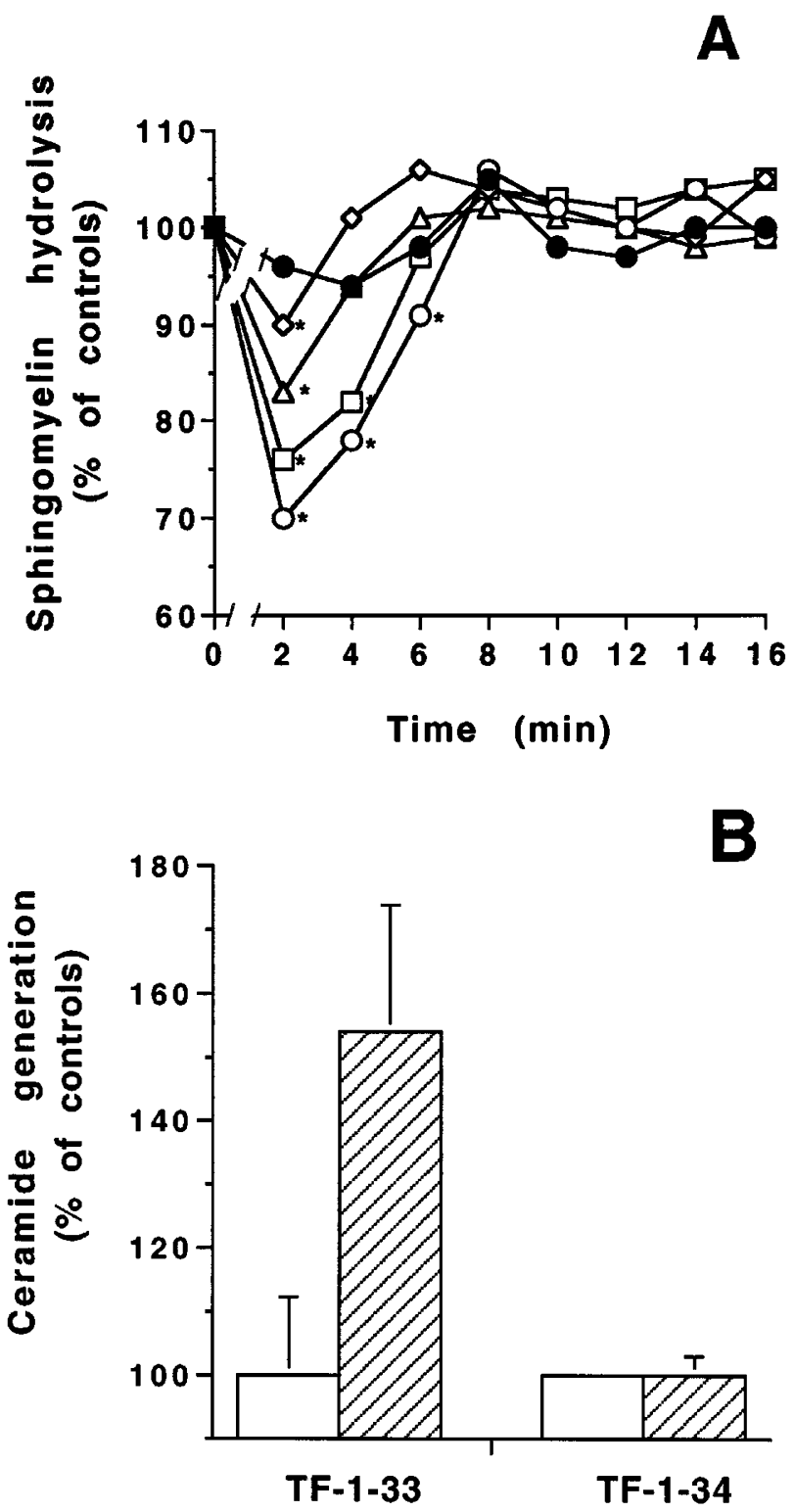

Figure 5 Induction of SM hydrolysis and CER generation in TF-1-33 and TF1-34 cells treated with IR. (A) SM levels were estimated in TF-1-33 (open symbols) and TF-1-34 (closed symbols) cells prelabeled with methyl- ${ }^{3} \mathrm{H}-$ choline for $48 \mathrm{~h}$. Cells were washed, resuspended in serum-free medium and irradiated at $2 \mathrm{~Gy}(\diamond), 6 \mathrm{~Gy}(\triangle), 12 \mathrm{~Gy}(\square)$ and $20 \mathrm{~Gy}(\boldsymbol{\bullet}, 0)$. Following incubation, aliquots were collected and lipids were extracted. Labeled SM was quantitated as described in Materials and Methods). Results are representative of three to six independent experiments and expressed as a percentage of control. S.E. $<10 \%$ (asterisks mean significant hydrolysis; $P<0.01$ ). (B) CER levels in control $(\square)$ or irradiated cells $(E / \triangle)$ were quantitated by the diacylglycerol kinase assay (see Materials and Methods). Results represent peak CER generation observed at peak SM hydrolysis. Values are the mean of triplicate determinations \pm S.E.M. and are representative of three independent experiments first cell cycle post-IR exposure. This early response to IR has been associated with the rapid and transient phosphorylationmediated inactivation of $\mathrm{p} 34^{\mathrm{cdc}-2}$ (Kharbanda et al, 1994). Therefore, it could be speculated that TF-1-34 cells display defective IR-mediated $\mathrm{p} 34^{\mathrm{cdc}-2}$ regulation.

The prevailing paradigm of the lethal effects of IR identifies DNA DSB as the critical lesions leading to cell death (Radford, 1986). Accordingly, it is generally believed that the inherent resistance of cells to IR is due primarily to their ability to repair DNA damage. In fact, in some mutant cell lines, decreased DNA repair resulted in enhanced sensitivity to IR-induced cytotoxicity (Warters et al, 1995). Since TF-1-34 cells were found to be more radioresistant than TF-1-33 cells, we compared IR-induced DNA damages in the two clones after 12 Gy IR exposure. We observed that IR produced comparable amounts of DSB of 1 to $10 \mathrm{Mbp}$.
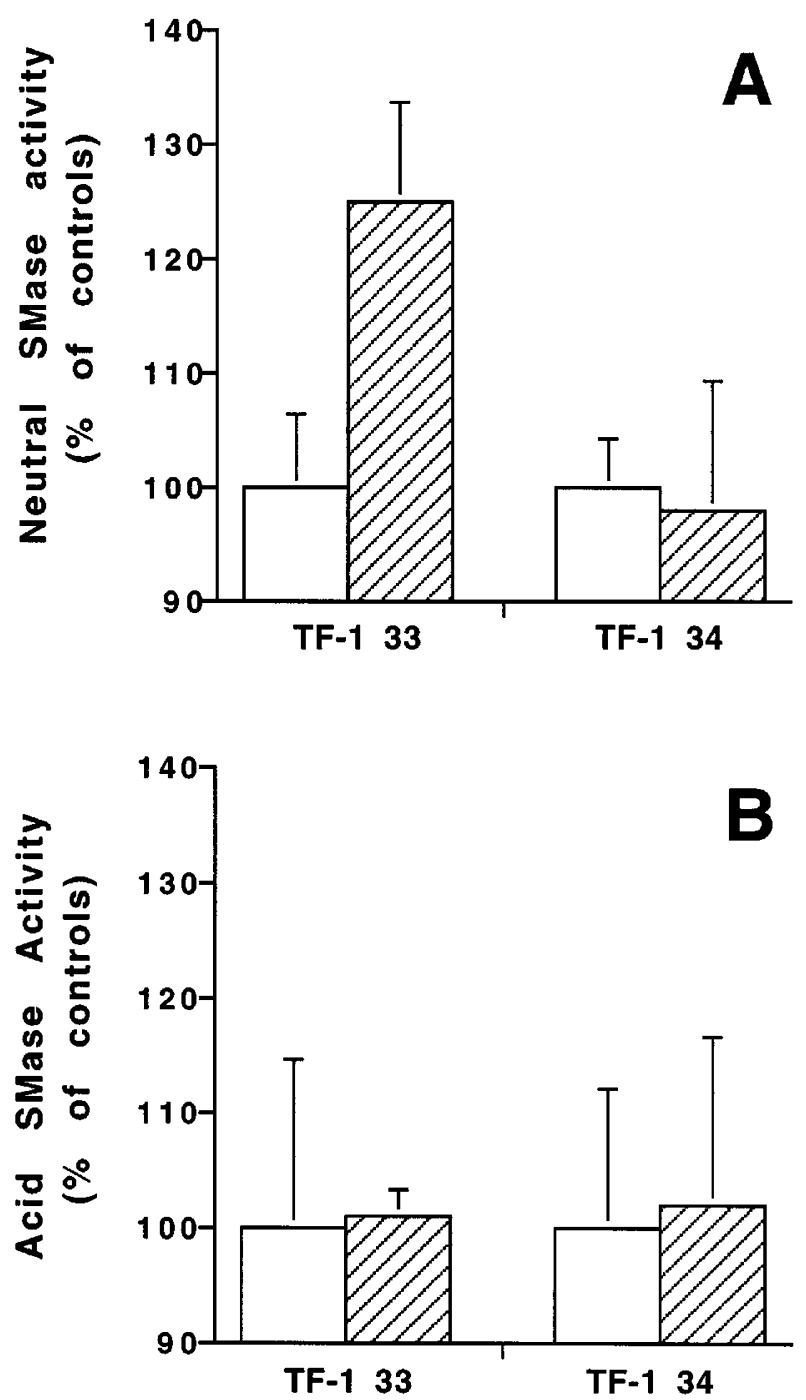

Figure 6 Effect of IR on SMases activities in TF-1-33 and TF-1-34 cells. Control cells $(\square)$ or irradiated cells $(E / \lambda)$ at 12 Gy were harvested at various time points and enzyme assays were performed as described in Materials and Methods. Results represent peak SMases activities observed at peak SM hydrolysis. Values are the mean of triplicate determinations and are representative of four independent experiments 
However, TF-1-34 retained these DSB much longer than TF1-33. The lack of DNA repair in TF-1-34 cells may have other important implications. Human hematopoietic progenitor cells have previously been shown to possess, in certain cases, low DNA repair enzymes such as $\mathrm{O}^{6}$-alkylguanineDNA transferase (Gerson et al, 1996). In our study, after 6 and 12 Gy exposure, an important fraction of TF-1-34 cells entered into $S$ phase and achieved DNA replication before DSB were removed whereas TF-1-33 cells were arrested in $S$ phase before dying by apoptosis. One could speculate that the absence of apoptosis in TF-1-34 cells may have severe mutagenic consequences when these cells are treated with lower doses (for example 6 Gy) thereby allowing for recovery of cell growth of a non negligible fraction $(10 \%)$ of the cell population. Furthermore, these observations also demonstrate that while TF-1-33 were able to repair large $>1 \mathrm{Mbp}$ DSB initially directly induced by IR, this cell line was not able to prevent DNA chromatin loop fragmentation of $50-600 \mathrm{Kbp}$ which appeared during the apoptotic process. Indeed, DNA macrofragmentation of $50-$ $600 \mathrm{Kbp}$ is a direct consequence of an apoptotic pathway (Oberhammer et al., 1993), and is not influenced by DNA repair capacity.

The lack of an apoptotic response of TF-1-34 could also be due to abnormal expression of proteins involved in the regulation of IR-induced apoptosis such as Bcl-2 (Sentman et al, 1991) or p53 (Fan et al, 1994). However, Bcl-2 expression was found similar in both TF-1-33 and TF-1-34, as assessed by Western blot and flow cytometry analysis (data not shown). However, we cannot rule out that other bcl-2 family genes play a role in the defective apoptotic response of TF-1-34 cells. For example, overexpression of $\mathrm{Bcl}-\mathrm{x}_{\mathrm{L}}$ by cytotoxic drug exposure confers resistance to IRinduced internucleosomal DNA fragmentation (Datta et al, 1995). Whether or not TF-1-34 and TF-1-33 cells display differences in bcl-2 related gene expression remains to be investigated. Nevertheless, it seems unlikely that such differences (if any) may account for the lack of CER generation in TF-1-34 cells. Indeed, as far as Bcl-2 is concerned, several recent reports demonstrated that $\mathrm{Bcl}-2$ blocked CER-induced apoptosis but did not interfere with CER generation induced by cytotoxic agents (Martin et al, 1995; Zhang et al, 1996; Smith et al, 1996; Allouche et al, 1997). As far as p53 is concerned, it should be noted that a mutated p53 gene has been documented in the parental TF-1 cell line (Sugimoto et al, 1992), and we have confirmed altered p53 mRNA in both TF-1-34 and TF-133 by reverse transcriptase-polymerase chain reaction single-strand conformational polymorphism analysis (Jaffrézou J.P., Bruno A.P. and Laurent G, unpublished observations). Thus, it can be reasonably speculated that IR-induced apoptosis in TF-1-33 cells can occur via a p53independent mechanisms as it has been demonstrated for other cellular models (Strasser et al, 1994). Moreover, mutated p53 may explain the lack of G1 arrest in irradiated TF-1-33 and TF-1-34 cells since the p53 product is required for IR-triggering G1 checkpoint (Kuerbitz et al, 1992) through p21 WAF1/CIP1 activation (Hunter, 1993). Indeed, we did not observe p21 induction in either cell line after 12 Gy irradiation (data not shown).
Since sensitivity to IR did not appear to correlate with DNA repair, and in light of the rising interest in apoptotic signaling pathways, we elected to evaluate the potential implication of CER in our two cellular models. CER has been implicated as a second messenger for a variety of apoptotic stimuli, including TNF $\alpha$ (Obeid et al, 1993), Fas ligand (Cifone et al, 1994) chemotherapeutic agents (Bose et al, 1995; Jaffrézou et al, 1996; Zhang et al, 1996), heat shock and oxidative stress (Verheij et al, 1996), and IR (Haimovitz-Friedman et al, 1994; Santana et al, 1996). In these studies, CER generation correlated closely with apoptosis. Moreover, treatment of cells with bacterial SMase or with cell-permeate CER analogs mimicked the apoptotic response. Using human myeloid leukemia cell lines, our study supports the hypothesis that CER acts as a second messenger in the signaling pathway of IR-induced apoptosis not only in normal, but also in tumor cells. Indeed, we found that in TF-1-33 cells, IR-triggered apoptosis and CER generation were dose-related while neither CER production nor apoptosis was detected in TF1-34 cells. Moreover, the observation that both cell lines were sensitive to cell permeate C6-CER induced apoptosis further supports the role of endogenous CER in IR-induced apoptosis.

The identification of the SMase(s) involved in CER generation has proven to be equivocal. Three forms of SMases are candidates for SM hydrolysis. Acid SMase $(\mathrm{pH}$ optimum 4.5-5.0) has been associated in apoptosis signaling triggered by TNF $\alpha$ (Wiegmann et al, 1994), antiFas (Cifone et al, 1994), and anti-CD28 (Boucher et al, 1995); activation of a membrane bound neutral SMase $(\mathrm{pH}$ optimum 7.4) has also been described with TNF $\alpha$ (Wiegmann et al, 1994), anti-Fas antibody (Tepper et al, 1995), IL-1 $\beta$ (Mathias et al, 1993) and daunorubicin (Jaffrézou et al, 1996); finally, a cytosolic neutral SMase has been implicated in vitamin D3 induced differentiation (Okazaki et al, 1994). A recent study by Kolesnick's group clearly demonstrated that acid SMase-deficient human lymphoblasts as well as lung endothelium, thymus and spleen of acid SMase knockout mice are defective in IRinduced apoptosis (Santana et al, 1996). These authors showed that retroviral transfer of acid SMase gene into these cells restored IR-induced CER generation and apoptosis. Surprisingly, these results conflicted with their previous report which suggested that neutral SMase may be involved in CER generation in irradiated bovine endothelial cells (Haimovitz-Friedman et al, 1994). In fact, our study identified neutral but not acid SMase as responsible for SM hydrolysis in irradiated TF-1 cells. Therefore, it appears probable that both acid and neutral forms of SMase may mediate IR-induced apoptosis depending on the cellular origin.

The reason for which IR did not induce SMase stimulation in TF-1-34 cells is unclear. However, it has been recently shown that calphostin $\mathrm{C}$ and chelerythrine, two potent and relatively specific protein kinase $C$ (PKC) inhibitors, induce CER production and apoptosis through activation of a neutral, but not acid, SMase (Chmura et al, 1996). Furthermore, PKC agonists such as phorbol esters, abrogated neutral SMase stimulation, CER generation and 
apoptosis in irradiated bovine endothelial cells apoptosis (Haimovitz-Friedman et al, 1994). These findings suggest an antagonistic relationship between PKC and neutral SMase activities. Therefore, we hypothesized that TF-1-34 cells may present higher basal PKC activity than TF-1-33 cells. However, the two TF-1 subclones exhibited similar PKC activity (data not shown). Alternatively, it is possible that, in TF-1-34 cells but not in TF-1-33 cells, IR could induce rapid PKC activation due to stimulation of phosphatidylinositol turnover (Uckun et al, 1993) or in relation with arachidonic acid production through phospholipase $\mathrm{A}_{2}$ activation (Hallahan et al, 1994); sustained PKC stimulation could be, in turn, responsible for SMase inhibition. These hypotheses are currently being tested in our laboratory.

Based on CD34 expression, it can be assumed that TF1-34 resistant cells display a less mature phenotype than TF-1-33 cells. We recently reported that other cytotoxic agents such as daunorubicin (Quillet-Mary et al, 1996) mitoxantrone (Bailly et al, 1997) and TNF $\alpha$ (Bettaïb et al, 1996) were also unable to induce apoptosis in CD34 expressing AML cells such as TF-1-34. Since in our study TF-1-34 cells were deficient in DNA repair, cell cycle arrest, and CER generation one could speculate on causality. Perhaps the lack of CER simply reflects the absence (or refusal) of cell damage recognition. Indeed, it is possible that the repression of the apoptotic program is a common feature of immature myeloid leukemia cells which offers a potential survival advantage to these cells compared to the more mature leukemia hemopoietic compartment. This hypothesis needs to be further investigated.

In conclusion, our study shows that IR induces different cellular response in two subclones of the TF-1 myeloid leukemic cell line. At doses comprised between 6 and 12 Gy, TF-1-33 cells engaged an interphase apoptotic cell death most likely by triggering neutral SMase, SM hydrolysis and subsequent CER generation. In TF-1-34 cells IR were unable to induce SMase stimulation and CER generation. The blockage of this signaling pathway may account for the lack of apoptosis and orients the cellular response to a reproductive cell death. While this manuscript was being completed, another group came to similar conclusions as ours, using IR sensitive and resistant murine lymphoid cells (Chmura et al, 1997). In concert, our studies reinforce the recent notion that neutral SMase is a critical upstream regulator of IR-induced cytotoxicity. The characterization of the molecular mechanism which acts as a negative regulator of neutral SMase in the resistant cells may lead to the identification of new radiosensitizers which could restore the apoptotic cell death pathway and subsequently increase the cytotoxicity of IR toward naturally resistant AML cells.

\section{Materials and Methods}

\section{Cells and cell culture}

The human erythro-myeloblastic cell line TF-1 (Kitumara et al, 1989) was generously provided by Dr. W. Vainchenker, INSERM U362,
Villejuif, France. TF-1 subclones were obtained by GM-CSF withdrawal and limited dilution. Two clones were chosen based on autonomous growth and phenotypic characteristics: TF-1-34 (CD34+, CD33-, CD38+, CD41+, glycophorin A-); TF-1-33 (CD34-, CD33+, CD38+, CD41+, glycophorin A-). Cells were cultured in RPMI 1640 medium supplemented with $10 \%$ heat-inactivated fetal calf serum, $2 \mathrm{mM}$ glutamine, 100 units $/ \mathrm{ml}$ penicillin and $100 \mu \mathrm{g} / \mathrm{ml}$ streptomycin (all from Eurobio, Les Ulis, France). Cells were maintained at $37^{\circ} \mathrm{C}$ in a humidified atmosphere containing $5 \% \mathrm{CO}_{2}$. Cell stocks were screened routinely for Mycoplasma (Stratagene Mycoplasma PCR kit, La Jolla, $\mathrm{CA})$.

\section{Drugs and reagents}

Aquasafe 300 scintillation cocktail was purchased from Berthold (Elancourt, France). Silica gel 60 thin-layer chromatography plates were from Merck (Darmstadt, Germany). All other drugs and reagents were purchased from Sigma Chemical Co. (St Louis, MO), Carlo Erba (Rueil-Malmaison, France), or Prolabo (Paris, France).

\section{Irradiation}

Irradiations were performed using a ${ }^{60} \mathrm{Co}$ source (1.25 MeV, Alcyon, General Electric) at a dose rate of approximately $1 \mathrm{~Gy} / \mathrm{min}$. For DNA repair assays cells were irradiated using a ${ }^{137} \mathrm{Cs}$ source (Cis-bio International).

\section{Clonogenic assays}

Clonogenic assays were performed as previously described (Laredo et al, 1993). Control and irradiated cells were seeded at preestablished optimal densities $\left(1 \times 10^{4}\right.$ and $\left.2 \times 10^{4}\right)$ in $35 \mathrm{~mm}$ Petri dishes containing RPMI, $30 \%$ fetal calf serum, $0.5 \mathrm{mM} \beta$-mercaptoethanol, and $0.9 \%$ methyl cellulose. After 7 days, colonies were scored under an inverted microscope. The surviving fraction was calculated at each dose level as the ratio of the colony numbers observed in the irradiated versus nonirradiated control. The best fit survival curve was then calculated by computer using the linear quadratic model (Fertil and Malaise, 1981, 1985). Statistical inference was performed using the Wilcoxon $t$-test.

\section{Morphological analysis}

Changes in cellular nuclear chromatin were evaluated by fluorescence microscopy by DAPI staining (Escargueil-Blanc et al, 1994).

\section{DNA analysis}

DNA was resolved on a $1.8 \%$ agarose gel and visualized with ethidium bromide as previously reported (Gong et al, 1994). Quantitative DNA fragmentation was determined by the spectrofluorometric DAPI procedure as previously described (McConkey et al, 1989; Kapuscinski and Skooczylaski, 1977).

\section{Pulsed-field gel electrophoresis}

Agarose plugs were prepared according to a previously published method (Filipski et al, 1990). $5 \times 10^{6}$ control and irradiated cells were embedded in $0.7 \%$ low-melting agarose plugs and incubated overnight at $50^{\circ} \mathrm{C}$ in $0.2 \mathrm{M}$ EDTA containing $10 \mathrm{mg} / \mathrm{ml}$ proteinase $\mathrm{K}$. The agarose plugs were washed three times for $1 \mathrm{~h}$ in $0.2 \mathrm{M}$ EDTA and stored at $4^{\circ} \mathrm{C}$ prior to analysis. The samples, including a $50-1000 \mathrm{Kbp}$ 
pairs lambda DNA standard (Promega Corporation, Madison, USA), were analyzed on a $1 \%$ agarose gel (SeaKem FastLane) using a SwitchBack ${ }^{\mathrm{TM}}$ Pulse Controller pulsed-field electrophoresis system (Hoefer Scientific Instruments, San Francisco, CA) at $100 \mathrm{~V}$ with pulse ramping times from 1 to $50 \mathrm{~s}$ (F/R ratio: $2.5: 1)$ for $18 \mathrm{~h}$ in a $0.5 \times$ TBE buffer ( $45 \mathrm{mM}$ Tris-borate, $1 \mathrm{mM}$ EDTA, $\mathrm{pH} 8$ ). The buffer was recirculated continuously at room temperature. The gels were stained with ethidium bromide $(0.5 \mathrm{mg} / \mathrm{ml})$ and photographed under UV illumination.

\section{Cell cycle analysis}

Control and irradiated cells were pulsed for 30 min with $25 \mu \mathrm{M}$ of bromodeoxyuridine (Boehringer Mannheim, Mannheim, Germany), washed in PBS and fixed in 70\% ethanol (Minn et al, 1995). Fixed cells were then pelleted, washed and further incubated in PBS containing $2.5 \mathrm{M} \mathrm{HCl}$ and $0.1 \%$ Triton $\mathrm{X}-100$ for $25 \mathrm{~min}$ at room temperature. Cells were then washed in neutralization/wash solution (PBS, $0.5 \%$ Tween-20) and resuspended in $100 \mu \mathrm{l}$ antibody-staining solution (PBS, $50 \%$ FCS, $0.01 \%$ sodium azide). Six microliters of fluorescein isothiocyanate (FITC)-conjugated anti-bromodeoxyuridine antibody (Boehringer Mannheim) was added and cells incubated at room temperature in the dark for $30 \mathrm{~min}$. Cells were washed twice with PBS containing $0.1 \%$ sodium azide and resuspended in $500 \mu \mathrm{l}$ PBS. Ten micrograms of propidium iodide was added and the samples were incubated for $60 \mathrm{~min}$ at room temperature in the dark. Samples were analyzed on a fluorescence-activated cell sorter (Facscan, BectonDickinson).

\section{Analysis of DNA DSB and DNA repair}

Analysis of DSB induction and DNA repair was performed essentially as previously described (Dhermain et al, 1995). Cells were radiolabeled by treating for $48 \mathrm{~h}$ with $0.3 \mu \mathrm{Ci} / \mathrm{ml}$ of methyl ${ }^{14} \mathrm{C}$ thymidine (2.12 MBq/mmole, Amersham, UK). After which, cells were embedded in $0.8 \%$ low melting point agarose (BRL, Bethesda, MD, USA). Tubes containing $2 \mathrm{ml}$ of serum-free RPMI medium, and 4-5 agar plugs (approximately $0.8-1.2 \mu \mathrm{g}$ of DNA) were exposed to $\gamma$ radiation $\left(1 \mathrm{~Gy} / \mathrm{min}\right.$ ) from a ${ }^{137} \mathrm{Cs}$ source (IBL 137 , Cis-bio international) at a dose range of $0,2.5,5,12,20,30$ and 40 Gy. After irradiation, cell plugs were treated with $0.5 \mathrm{M}$ EDTA, $2 \%$ Sarkosyl, $1 \mathrm{mg} / \mathrm{ml}$ proteinase $\mathrm{K}$ at $50^{\circ} \mathrm{C}$ for $24 \mathrm{~h}$, washed twice with Tris-EDTA buffer (1 mM EDTA and $10 \mathrm{mM}$ Tris- $\mathrm{HCl}, \mathrm{pH}$ 8). Proteinase $\mathrm{K}$ activity was stopped by adding $20 \mu \mathrm{l}$ of $12 \%$ PEFA-Block solution for $1 \mathrm{~h}$ (Interchim, France). Plugs of control and irradiated samples together with plugs of molecular weight marker, Schizosaccharomyces pombe and Schizosaccharomyces cerevisiae (BioRad) were inserted into the wells of a $0.8 \%$ agarose gel. The gel was placed into the $\mathrm{CHEF}$ apparatus (CHEF Mapper ${ }^{\mathrm{TM}}$, BioRad) containing permanently circulating $1 \times$ TAE (40 mM Tris acetate and $2 \mathrm{mM}$ EDTA) maintained at $12^{\circ} \mathrm{C}$ by $\mathrm{CHEF}$ Chiller (BioRad). The condition for CHEF electrophoresis were: $74 \mathrm{~h}$ total migration time at $2 \mathrm{~V} / \mathrm{cm}$ with an angle of reorientation $+/-53^{\circ}\left(106^{\circ}\right)$ and a pulse time of $35 \mathrm{~min}$. After the electrophoretic run the gel was stained in ethidium bromide, destained and visualized by UV transillumination. DNA was quantified by image analysis (Biocom, France) using LECPHOR software. In order to evaluate the radioactivity after electrophoresis when the cells were radioactively labeled, the lanes including the wells (visualized by ethidium bromide staining) were separated and each lane cut into $5 \mathrm{~mm}$ segments (22 per lane), each segment was dissolved in $400 \mu \mathrm{l}$ $1 \mathrm{M} \mathrm{HCl}$ at $95^{\circ} \mathrm{C}$, neutralized with $1 \mathrm{M} \mathrm{NaOH}$, mixed with $4 \mathrm{ml}$ of scintillation liquid and counted. The fraction of DNA (activity) released from the well (FAR) (Blöcher, 1989) in the unirradiated sample (and its average) was calculated according to the following formula: d.p.m. in the lane of $\times$ Gy/d.p.m. in the lane of $\times$ Gy+d.p.m. in the well. The fraction of extracted DNA found in the control sample (0 Gy) was systematically substracted from all the fractions of extracted DNA found in the various irradiated samples. Finally, we plotted in the graphs the corrected fractions of extracted DNA (FAR) lane $\times$ Gy minus (FAR) lane 0 Gy as a function of irradiation doses.

\section{Metabolic cell labeling and sphingolipid quantitation}

SM quantitation was performed by labeling cells to isotopic equilibrium with $0.4 \mu \mathrm{Ci} / \mathrm{ml}$ of [methyl- ${ }^{3} \mathrm{H}$ ]choline (specific activity $81.0 \mathrm{Ci} / \mathrm{mmol}$, DuPont-NEN, Les Ulis, France) for $48 \mathrm{~h}$ in complete medium as previously described (Jaffrézou et al, 1996; Andrieu et al, 1994). Cells were then washed and resuspended in serum-free medium for kinetic experiments. Aliquots were taken for protein determination (Smith et al, 1985). Radioactive SM was extracted (Folch et al, 1957; Stoffel and Metzner, 1980) and quantitated by scintillation counting. Similar results for SM quantitation were obtained after thin layer chromatography, where SM spots were identified based on Rf and co-migration with authentic standards (data not shown).

Total cellular CER quantitation was quantitated using $E$. coli diaclyglycerol kinase (Amersham, kit no. RPN200) and $\left[{ }^{33} \mathrm{P}\right] \gamma$-ATP (3300 Ci/mmol, Isotopchim, Ganagobie, France) according to previously published procedures (Van Veldoven et al, 1992). Statistical analyses were performed by the Student's $t$-test.

\section{Quantitation of acid and neutral SMase activities}

SMase assays were performed as previously described (Wiegmann et al, 1994) using [choline-methyl- ${ }^{14} \mathrm{C}$ ]SM (120 000 d.p.m./assay) as substrate (Jaffrézou et al, 1996).

\section{Acknowledgements}

This work was supported by a grant from the Actions Concertées Coordonnées-Sciences du Vivant ACCSV8: 9508008 (G.L.) and by La Fédération Nationale des Centres de Lutte Contre le Cancer 96003115 (J.P.J. and T.L.), and in part by the Conseil Régional Midi-Pyrénées (T.L. and J.P.J.), I'Association pour la Recherche sur le Cancer Grants 6749 (G.L.), 3002 (T.L.), and 2069 (J.P.J.), and by La Ligue Nationale Contre le Cancer (G.L.). A.P.B. is the recipient of a grant from the Ministère de l'Education Nationale, de l'Enseignement Supérieur et de la Recherche (MENESR).

Our gratitude is extended to Dr. G. Noël (CNRS UMR 218, Paris) ${ }^{*}$, R. Blaise (CJF INSERM 9503, Toulouse) and C. Bousquet (Service d'Hematologie, Toulouse) for their expert technical assistance; Dr. W. Vainchenker (INSERM U 362, Villejuif) for kindly providing us with the TF-1 cell line and to Drs. F. Larminat and C. Cayrol (CNRS UPR 9062, Toulouse) for p53 and p21 analysis, respectively. We also thank Pr. B. Ducommun (CNRS UPR 9062, Toulouse) and Pr. J.M. Cosset (Institut Curie, Paris) for helpful discussions, and the cooperation of Pr. Daly (Centre Claudius Regaud, Toulouse).

\section{References}

Allouche M, Bettaïeb A, Vindis C, Rousse A, Grignon C and Laurent G (1997) Influence of $\mathrm{Bcl}-2$ overexpression on the ceramide pathway in daunorubicininduced apoptosis of leukemic cells. Oncogene 14: 1837-1845 
Andrieu N, Salvayre Rand Levade T (1994) Evidence against involvement of the acid lysosomal sphingomyelinase in the tumor-necrosis-factor- and interleukin-1induced sphingomyelin cycle and cell proliferation in human fibroblasts. Biochem. J. 303: 341-345

Bailly JD, Skladanowski A, Bettaïeb A, Mansat V, Larsen A and Laurent G (1997) Natural resistance of acute myeloid leukemia cell lines to mitoxantrone is associated with lack of apoptosis. Leukemia 11: 1523-1532

Bettaïeb A, Record M, Côme MG, Bras AC, Chap H, Laurent G and Jaffrézou JP (1996) Opposite effects of TNF $\alpha$ on the sphingomyelin-ceramide pathway in two myeloid leukemia cell lines: role of transverse sphingomyelin distribution in the plasma membrane. Blood 88: 1465-1472

Blöcher D (1989) CHEF electrophoresis, a linear induction of double strand breaks corresponds to a non linear fraction of extracted DNA with dose. Int. J. Radiat. Biol. 56: 437-448

Bose R, Verheij M, Haimovtiz-Friedman A, Scotto K, Fuks Z and Kolesnick R (1995) Ceramide synthase mediates daunorubicin-induced apoptosis: an alternative mechanism for generating death signals. Cell 82: 405-414

Boucher LM, Wiegman K, Fütterer A, Pfeffer K, Machleidt T, Shütze S, Mak TW and Krönke M (1995) CD28 signals through acidic sphingomyelinase. J. Exp. Med. 181: 2059-2068

Bump EA, Braunhut SJ, Palayoor ST, Medeiros D, Lai LL, Cerce BA, Langley RE and Coleman CN (1994) Novel concepts in modification of radiation sensitivity. Int. J. Radiat. Oncol. Biol. Phys. 29: 249-253

Cifone MC, De Maria R, Roncaioli P, Rippo MR, Azuma LLM, Lanier LL, Santoni A and Testi R (1994) Apoptotic signaling through CD95 (Fas/Apo-1) activates an acidic sphingomyelinase. J. Exp. Med. 177: 1547-1552

Chang WP and Little JB (1991) Delayed reproductive death in X-irradiated chinese hamster ovary cells. Int. J. Radiat. Biol. 60: 483-496

Chmura SJ, Nodzenski E, Weichselbaum RR and Quintans J (1996) Protein kinase C inhibition induces apoptosis and ceramide production through activation of a neutral sphingomyelinase. Cancer Res. 56: 2711-2714

Chmura SJ, Nodzenski E, Beckett MA, Kufe DW, Quintans J and Weichselbaum RR (1997) Loss of ceramide production confers resistance to radiation-induced apoptosis. Cancer Res. 57: 1270-1275

Datta R, Manome Y, Taneja N, Boise LH, Weichselbaum R, Thompson CB, Slapak $\mathrm{CA}$ and Kufe D (1995) Overexpression of Bcl-xl by cytotoxic drug exposure confers resistance to ionizing radiation-induced internucleosomal DNA fragmentation. Cell Growth Differ. 6: 363-370

Dhermain F, Dardalhon M, Queinnec E and Averbeck D (1995) Induction of doublestrand breaks in chinese hamster ovary cells at two different dose rates of $\gamma$ irradiation. Mutation Res. 336: 161-167

Escargueil-Blanc I, Salvayre Rand Nègre-Salvayre A (1994) Necrosis and apoptosis induced by oxidized low density lipoproteins occur through two calciumdependent pathways in lymphoblastoid cells. FASEB J. 8: 1075-1080

Fan S, EI-Deiry WS, Bae I, Freeman J, Jondle D, Bhatia K, Fornace AJ, Magrath I, Kohn KW and O'Connor PM (1994) p53 gene mutations are associated with decreased sensitivity of human lymphoma cells to DNA damaging agents. Cancer Res. 54: 5824-5830

Fertil B and Malaise EP (1981) Inherent cellular radiosensitivity as a basic conceptfor human tumor radiotherapy. Int. J. Radiat. Oncol Biol. Phys. 7: 621-629

Fertil B and Malaise EP (1985) Intrinsic radiosensitivity of human cell line is correlated with radioresponsiveness of human tumors: analysis of 101 published survival curves. Int. J. Radiat. Oncol. Biol. Phys. 11: 1699-1707

Filipski J, Leblanc J, Youdale T, Sikorska M and Walker PR (1990) Periodicity of DNA folding in higher order chromatin structures. EMBO J. 9: 1319-1327

Folch J, Lees M and Sloane-Stanley GH (1957) A simple method for the isolation and purification of total lipids from animal tissues. J. Biol. Chem. 226: 497-509

Foray N, Badie C, Alsbeith G, Fertil B and Malaise EP (1996) A new model describing the curves for repair of both DNA double-strand breaks and chromosome damage. Radiation Res. 146: 53-60

Gerson SL, Philips W, Kastan M, Dumenco LL and Donovan C (1996) Human CD34+ hematopoietic progenitors have low, cytokine-unresponsive $0^{6}$-alkylguanineDNA alkyltransferase and are sensitive to $0^{6}$-benzylguanine plus BCNU. Blood 88: $1649-1655$

Gong J, Traganos F and Darzynkiewicz Z (1994) A selective procedure for DNA extraction from apoptotic cells applicable for gel electrophoresis and flow cytometry. Anal. Biochem. 218: 314-319

Haimovitz-Friedman A, Kan CC, Ehleiter D, Persaud RS, McLoughlin M, Fuks Z and Kolesnick RN (1994) lonizing radiation acts on cellular membranes to generate ceramide and initiate apoptosis. J. Exp. Med. 180: 525-535
Hallahan DE, Virudachalam S, Kuchibhotla J, Kufe DW and Weichselbaum RR (1994) Membrane-derived second messenger regulates x-ray-mediated tumor necrosis factor $\alpha$ gene induction. Proc. Natl. Acad. Sci. U.S.A. 91: 4897-4901

Hannun YA (1996) Functions of ceramide in coordinating cellular responses to stress. Science 274: 1855-1859

Hofer KG (1970) Radiation effects on death and migration of tumor cells in mice. Radiat. Res. 43: 663-678

Hunter T (1993) Braking the cycle. Cell 75: 839-841

JaffrézouJP, Levade T, Bettaïeb A, Andrieu N, Bezombes C, Maestre N, Vermeersch S, Rousse A and Laurent G (1996) Daunorubicin-induced apoptosis: triggering of ceramide generation through sphingomyelin hydrolysis. EMBO J. 15: 24172424

Kapuscinski J and Skooczylaski B (1977) Simple and rapid fluorometric method for DNA microassay. Anal Biochem. 83: 252-257

Kharbanda S, Saleem A, Datta R, Yuan Zm, Weichelbaum RR and Kufe DW (1994) Ionizing radiation induces rapid tyrosine phosphorylation of $p 34 c d c-2$. Cancer Res. 54: 1412-1414

Kitamura T, Tange T, Terasawa T, Chiba S, Kuwaki T, Miyagawa K, Piao YF, Miyazono K, Urabe A and TakakuF (1989) Establishment and characterization of a unique human cell line that proliferates dependently on GM-CSF, IL-3, or erythropoietin. J. Cell Physiol. 140: 323-334

Kuerbitz SJ, Plunkett BS, Walsh WV and Kastan MB (1992) Wild-type p53 is a cell cycle checkpoint determinant following irradiation. Proc. Natl. Acad. Sci. U.S.A. 89: $7491-7495$

Laredo J, Demur C, Muller C, Saivin S, Cassar G, Bousquet C, Dastugue N, Jaffrézou JP, Colombies P and Laurent G (1993) Effects of $\mathrm{H}-7$ and staurosporine on proliferation and self-renewal of acute myeloid leukemia progenitors. Leukemia 7: $813-820$

Ling CC, Hu Chen C and Li WX (1994) Apoptosis induced at different dose rates: implication for the shoulder region of cell survival curves. Radiother. Oncol. 32: $129-136$

Martin SJ, Takayama S, McHahon AJ, Miyashita T, Corbeil J, Kolesnick RN, Reed JC and Green DR (1995) Inhibition of ceramide-induced apoptosis by Bcl-2. Cell Death Differ. 26: 253-257

Mathias S, Younes A, Kan CC, Orlow I, Joseph C and Kolesnick RN (1993) Activation of the sphingomyelin pathway in intact EL4 and in a cell-free system by IL-1 $\beta$. Science 259: 519-522

McConkey DJ, Aguilar-Santelises M, Harztell P, Eriksson I, Mellstedt H, Orrenius S and Jondal M (1989) Induction of DNA fragmentation in chronic B-lymphocytic leukemia cells. J. Immunol. 146: 1072-1077

Meyn RE, Stephens LC, Ang KK, Hunter NR, Brock WA, Milas Land Peters LJ (1993) Heterogeneity in the development of apoptosis in irradiated murine tumours of different histologies. Int. J. Radiat. Biol. 64: 583-591

Minn AJ, Rubin CM, Boise LH and Thompson CB (1995) Expression of Bcl-xL can confer a multidrug resistance phenotype. Blood 86: 1903-1910

Obeid LM, Linardic CM, Karolak LA and Hannum YA (1993) Programmed cell death induced by ceramide. Science 259: 1769-1771

Oberhammer F, Wilson JW, Dive C, Morris ID, Hickman JA, Wakeling AE, Walker PR and Sikorska M (1993) Apoptotic death in epithelial cells: cleavage of DNA to 300 and/or $50 \mathrm{~kb}$ fragments prior to or in the absence of internucleosomal fragmentation. EMBO J. 12: 3679-3684

Okazaki T, Bielawska A, Domae N, Bell RM and Hannun YA (1994) Characteristics and partial purification of a novel cytosolic, magnesium-independent, neutral sphingomyelinase activated in the early signal transduction of $1 \alpha, 25$ dihydroxyvitamin $\mathrm{D}_{3}$-induced $\mathrm{HL}-60$ cell differentiation. J. Biol. Chem. 269: 4070-4077

Ploemacher RJ, Van Os R, Van Beurden CAJ and Down JD (1992) Murine haematopoietic cells stem cells with long-term engraftment and marrow repopulating ability are more resistant to gamma-radiation than are spleen colony forming cells. Int. J. Radiat. Biol. 61: 489-499

Quillet-Mary A, Mansat V, Duchayne E, Côme MG, Allouche M, Bailly JD, Bordier C and Laurent $G$ (1996) Daunorubicin-induced internucleosomal DNA fragmentation in acute myeloid cell lines. Leukemia 10: 417-425

Radford IR (1986) Evidence for a general relationship between the induced level of DNA double-strand breakage and cell-killing after X-irradiation of mammalian cells. Int. J. Cancer 49: 611-620

Santana P, Pena LA, Haimovitz-Friedmann A, Martin S, Green D, McLoughlin M, Cordon-Cardo C, Schuchman EH, Fuks Z and Kolesnick R (1996) Acid SMasedeficient human lymphoblasts and mice are defective in radiation-induced apoptosis. Cell 86: $189-199$ 
Sentman CL, Shutter JR, Hockenbery D, Kanagawa O and Korsmeyer SJ (1991) bcl2 inhibits multiple forms of apoptosis but not negative selection in thymocytes. Cell 67: 879-888

Smith PK, Krohn RI, Hermanson GT, Mallia AK, Gartner FH, Provenzano MD, Fujimoto EK, Goeke NM, Olson BJ and Klenk DC (1985) Measurement of proteins using bicinchoninic acid. Anal. Biochem. 150: 76-85

Smyth MJ, Perry DK, Zhang J, Poirier GG, Hannun YA and Obeid LM (1996) prICE: a downstream target for ceramide-induced apoptosis and for the inhibitory action of Bcl-2. Biochem. J. 316: 25-28

Stoffel W and Melzner I (1980) Studies in vitro on the biosynthesis of ceramide and sphingomyelin. A reevaluation of proposed pathways Hoppe-Seyler's Z. Physiol. Chem. 361: 755-771

Strasser A, Harris AW, Jacks T and Cory S (1994) DNA damage can induce apoptosis in proliferating lymphoid cells via p53-independent mechanisms inhibitable by Bcl-2. Cell 79: 329-339

Sugimoto K, Toyoshima H, Sakai R, Miyagawa K, Hagiwara K, Ishikawa F, Tabaku F, Yasaki $Y$ and Hirai $H$ (1992) Frequent mutations in the p53 gene in human myeloid leukemia cell lines. Blood 79: 2378-2383

Soldatenkov VA, Denisenko MF, Khodarev NN, Votrin II, Filippovich IV (1989) Early post-irradiation chromatin degradation in thymocytes. Int. J. Radiat. Res. 55: 943-951

Tepper CG, Jayadev S, Liu B, Bielawska A, Wolff R, Yonehara S, Hannun YA and Seldin MF (1995) Role for ceramide as an endogenous mediator of Fas-induced cytotoxicity. Proc. Natl. Acad. Sci. U.S.A. 92: 8443-8447
Tounekti O, Pron G, Belehradek J and Mir LM (1993) Bleomycin, an apoptosismimetic drug that induces two types of cell death depending on the number of molecules internalized. Cancer Res. 53: 5462-5469

Uckun FM, Schieven GL, Tuel-Ahlgren LM, Dibirdik I, Myers DE, Ledbetter JA and Song CW (1993) Tyrosine phosphorylation is a mandatory proximal step in radiation-induced activation of the protein kinase $C$ signaling pathway in human B-lymphocyte precursors. Proc. Natl. Acad. Sci. U.S.A. 90: 252-256

VanVeldoven IP, Matthiews TJ, Boloniesi DP and Bell RM (1992) Changes in bioactive lipids, alkylacylglycerol and ceramide occur in HIV infected cells. Biochem. Biophys. Res. Com. 187: 209-216

Verheij M, Bose R, Lin XH, Yao B, Jarvis WD, Grant S, Birrer MJ, Szabo E, Zon LI, Kyriakis JM, Haimovitz-Friedman A, Fuks Z and Kolesnick RN (1996) Requirement for ceramide-initiated SAPK/JNK signalling in stress-induced apoptosis. Nature 380: 75-79

Wiegmann K, Schutze S, Machleidt T, Witte D and Kronke M (1994) Functional dichotomy of neutral and acidic sphingomyelinase in tumor necrosis factor signaling. Cell 78: 1005-1015

Warters RL, Barrows LR and Chen DJ (1995) DNA double-strand break repair in two radiation-sensitive mouse mammary carcinoma cell lines. Mut. Res. 336: 1-7

Yamada T and Ohyama H (1988) Radiation-induced interphase death of rat thymocytes is internally programmed (apoptosis). Int. J. Radiat. Biol. 53: 65-75

Zhang J, Alter N, Reed JC, Borner C, Obeid LM and Hannun YA (1996) Bcl-2 interrupts the ceramide-mediated pathway of cell death. Proc. Natl. Acad. Sci. U.S.A. $93: 5325-5328$ 